\title{
Invoking freedom of expression and freedom of competition in trade mark infringement disputes: legal mechanisms for striking a balance
}

\author{
Łukasz Żelechowski ${ }^{1}$
}

Published online: 21 February 2018

(C) The Author(s) 2018. This article is published with open access at Springerlink.com

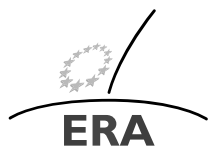

EUROPÄISCHE RECHTSAKADEMIE ACADEMY OF EUROPEAN LAW ACADEMIE DE DROIT EUROPEEN ACCADEMIA DI DIRITTO EUROPEO

TRIER - TREVES - TREVIRI

\begin{abstract}
The article explores legal mechanisms for striking a balance of competing interests on the premise of freedom of expression and freedom of competition in the area of trade mark infringement. Special focus is given to the respective framework under the reformed EU trade mark law. The paper argues that the newly introduced references to fundamental rights and freedoms in the preambles of relevant acts should play a crucial role in interpreting and applying provisions of trade mark law at all stages of assessing an infringement action. As for specific issues, the paper, notably, discusses the potential for providing a balance of interests resting in the 'due cause' clause and the amended catalogue of limitations and exceptions, arguing in particular that the narrowing of the own name and address limitation to natural persons properly balances the interests at stake. Finally, the paper questions the inapplicability of national correction instruments to trade mark infringement matters, implied in the case law of the Court of Justice.
\end{abstract}

Keywords Trade marks · Freedom of expression - Undistorted competition · Limitations and exceptions · Due cause

The author would like to thank Dr Jennifer Davis for her valuable comments on an earlier draft of this paper. All mistakes and omissions are the author's own. This publication was prepared in the course of a research project funded by the National Science Centre, Poland (project no 2014/13/D/HS5/01450).

$凶$ Ł. Żelechowski

1.zelechowski@wpia.uw.edu.pl

1 Dr, Assistant Professor, Faculty of Law and Administration, University of Warsaw, ul. Krakowskie Przedmieście 26/28, 00-927 Warszawa, Poland 


\section{Introduction}

The need to reconcile protection of trade mark rights, being property rights under Art. 1 of the First Protocol to the European Convention on Human Rights (the ECHR) ${ }^{1}$ and under Art. 17(2) of the Charter of Fundamental Rights of the EU (the Charter), ${ }^{2}$ with other fundamental rights and freedoms has grown in importance in recent years and has been largely elaborated in legal literature. ${ }^{3}$ The increasing significance of this issue has interrelated with the noticeable quest for striking a balance betweenon one hand-interests of the trade mark proprietors resting in effective protection of their rights and - on the other hand — other competing interests, including interests of competitors in the marketplace in preventing trade mark law from introducing unnecessary market entry barriers, interests of consumers of goods and services resting in protecting them against confusion and any other distortions of competition which could negatively affect the process of making their market decisions, and also interests of the public at large in having access to the use of protected trade marks in public discourse. ${ }^{4}$ While the shape of the pre-reformed EU trade mark law, contained in the Trade Mark Directive 2008/95 (TMD 2008) ${ }^{5}$ and the Community Trade Mark Regulation No 207/2009 (CTMR 2009), ${ }^{6}$ could be perceived as reflecting the neo-liberal assumption that all actors on the market have equal positions and that law should intervene in the market to the minimal extent, the development of case law of the Court of Justice of the European Union (the CJEU) and of national courts has proven, that there might be instances in which there is a need for an intervention taking the form of a balancing of interests of various actors at play. ${ }^{7}$

A particularly sensitive area is the balancing of interests of trade mark proprietors against the aforementioned competing interests with a view to securing freedom of expression and freedom of competition (commerce). ${ }^{8}$ The paper focuses on this specific interface and does so with regard to trade mark infringement which is the area where the need for providing a respective balance has particularly strongly manifested itself in case law (as discussed in point 3). The goal, however, is less to provide a detailed analysis of case law, but rather to take a more systematic and general perspective of available legal mechanisms for striking a proper balance with a

\footnotetext{
${ }^{1}$ Convention for the Protection of Human Rights and Fundamental Freedoms (European Convention on Human Rights), Rome, 4.11.1950, http://www.echr.coe.int/Documents/Convention_ENG.pdf (accessed 8.1.2018).

${ }^{2}$ [2012] OJ C 326/391.

${ }^{3}$ With regard to the EU law e.g. Geiger [10]; Bently [2]; Burrell, Gangjee [3]; Sakulin [19]; Ramsey, Schovsbo [17]; Fhima [9]; Senftleben [24]; Senftleben et al. [23]; von Kapff [12]; Schovsbo [20].

${ }^{4}$ Study [27], pp. 55-59 paras. 1.40-1.51; Davis [7]; Senftleben et al. [23].

${ }^{5}$ Directive 2008/95/EC of the European Parliament and of the Council of 22 October 2008 to approximate the laws of the Member States relating to trade marks [2008] OJ L 299/25; it replaced the earlier Directive $89 / 104$.

${ }^{6}$ Council Regulation (EC) No 207/2009 of 26 February 2009 on the Community trade mark [2009] OJ L 78/1; it replaced the earlier Regulation No 40/94.

${ }^{7}$ Davis [7], notably p. 128.

${ }^{8}$ Opinion of AG Poaires Maduro in Joined Cases C-236/08 to C-238/08 Google, EU:C:2009:569, para. 102; Senftleben et al. [23].
} 
particular emphasis on the situation in the light of the reformed EU trade mark law contained in the Trade Mark Directive 2015/2436 (TMD 2015) ${ }^{9}$ and the current European Trade Mark Regulation 2017/1001 (EUTMR 2017). ${ }^{10}$ The structure of the paper is determined by the sequential approach towards the assessment of a trade mark infringement action. First, respective balancing tools are searched for at the stage of assessment of infringement criteria (point 3.1). The analysis moves next to the role of catalogue of express limitations and exceptions to exclusive trade mark rights (point 3.2) and to the 'due cause' clause available in the case of extended protection of trade marks with a reputation (point 3.3). Finally, the possibility of taking into account external balancing tools contained in national unfair competition laws or in general private law clauses on abuse of rights is taken under scrutiny (point 3.4).

\section{Fundamental rights and the shape of EU trade mark law}

Prior to the EU trade mark law reform no references to fundamental rights and freedoms could be found in the texts of the TMD 2008 and the CTMR 2009. After the reform such explicit references are still not contained directly in the provisions of the TMD 2015 and the EUTMR 2017. They appear, however, in the preambles of both acts: in Recital 27 TMD 2015 in fine and Recital 21 EUTMR 2017 in fine which stipulate that both acts 'should be applied in a way that ensures full respect for fundamental rights and freedoms, and in particular the freedom of expression'. Even though both recitals deal primarily with the issue of limitations and exceptions to exclusive trade mark rights, the framing of references to fundamental rights and freedoms can be construed as a general call for taking them into account in the process of interpreting and applying trade mark law. ${ }^{11}$

The freedom of expression which is specifically distinguished among other fundamental rights and freedoms in the preamble of the TMD 2015 and the EUTMR 2017, is guaranteed under Art. 10(1) ECHR and Art. 11 of the Charter. In the light of the case law of the European Court of Human Rights (ECtHR) a guarantee of freedom of expression contained in Art. 10(1) ECHR applies to any type of message, including commercial advertising ${ }^{12}$ and trade mark application. ${ }^{13}$

As far as freedom of competition is concerned, it is regarded as one of the elements combining freedom to conduct business in the light of Art. 16 of the Charter, as reflected in the explanations to the Charter which stipulate that the protection afforded by Art. 16 covers the freedom to exercise an economic or commercial activity, the freedom of contract and free competition. ${ }^{14}$ This has also been confirmed in the

\footnotetext{
${ }^{9}$ Directive (EU) 2015/2436 of the European Parliament and of the Council of 16 December 2015 to approximate the laws of the Member States relating to trade marks [2015] OJ L 336/1.

${ }^{10}$ Regulation (EU) $2017 / 1001$ of the European Parliament and of the Council of 14 June 2017 on the European Union trade mark [2017] OJ L 154/1.

${ }^{11}$ Schovsbo [20], p. 14.

${ }^{12}$ Casado Coca v. Spain, appl. no. 15450/89, paras. 35-37.

${ }^{13}$ Dor v. Romania, appl. no. 55153/12, para. 43.

${ }^{14}$ Explanations relating to the Charter of Fundamental Rights [2007] OJ C 303/17; notes to Art. 16.
} 
case law of the Court of Justice (the Court). ${ }^{15}$ It should be noted that the Court enunciated on many occasions that trade mark rights constitute an essential element of the system of undistorted competition. ${ }^{16}$ With regard to trade mark infringement proceedings freedom of competition might overlap with freedom of expression, namely when freedom of commercial expression needs to be balanced against trade mark rights in such instances like use of non-distinctive or descriptive signs in unauthorised user's own commercial communication or referential use, e.g. in comparative advertising, as a keyword in online search engines for the purpose of informing consumers about an alternative offer or when using a trade mark in a satirical or artistic manner still, however, in a commercial context and in relation to goods and services. A further problem concerns conflicts between trade names and trade marks. Legal mechanisms for striking a competition-friendly balance of interests in the abovementioned instances will be discussed in this paper (see point 3). Extending the analysis to such areas like exhaustion of trade mark rights (Art. 15 TMD 2015; Art. 15 EUTMR 2017) and the newly introduced provisions on goods in transit (Art. 10(4) TMD 2015; Art. 9(4) EUTMR 2017) where tensions between the scope of trade mark rights and considerations of free competition are certainly present, did not appear viable, given the limited scope of the paper.

\section{Mechanisms for striking a balance}

\subsection{Infringement criteria}

\subsubsection{Applying the criteria of use 'in the course of trade' and use 'in relation to goods and services'}

Two general infringement criteria-use 'in the course of trade' and use 'in relation to goods and services' (Art. 10(2) TMD 2015; Art. 9(2) EUTMR 2017)—have already to some extent been employed in the case law for the purpose of balancing of interests on the premise of freedom of expression and freedom of competition.

As regards use in the course of trade, the Court construes it as use that 'takes place in the context of commercial activity with a view to economic advantage and not as a private matter' ${ }^{17}$ and in the user's own commercial communication. ${ }^{18}$ Consequently this criterion allows separating commercial use from use which takes place entirely in a non-commercial context and is directed to the public at large. This might be particularly relevant for excluding non-commercial use made for purely artistic, political or satirical purposes from the ambit of trade mark infringement. An example of use

\footnotetext{
${ }^{15}$ Case C-283/11 Sky Österreich, EU:C:2013:28, para. 42; Case C-477/14 Pillbox 38, EU:C:2016:324, para. 155; Case C-201/15 AGET Iraklis, EU:C:2016:972, para. 67.

${ }^{16}$ Case C-10/89 HAG, EU:C:1990:359, para. 13; Case C-517/99 Merz \& Krell, EU:C:2001:510, para. 21; Case C-206/01 Arsenal, EU:C:2002:651, para. 47.

${ }^{17}$ Case C-206/01 Arsenal, para. 40.

${ }^{18}$ Joined Cases C-236/08 to C-238/08 Google, EU:C:2010:159, para. 56; Case C-379/14 TOP Logistics, EU:C:2015:497, para. 41.
} 
not considered to take place in the course of trade could be the French Esso case ${ }^{19}$ in which use of the terms ESSO, STOP ESSO, E\$O and STOP E\$ \$O (as words and sometimes along with figurative elements) was considered as not commercial, but rather polemical with regard to the environmental policy of the oil company and not exceeding the limitations of the freedom of speech. An example pertaining to purely political speech can be found in the UK case Unilever ${ }^{20}$ in which the use in a political broadcast of the popular spread brand MARMITE was considered to neither constitute use in the course of trade, nor use in relation to goods and services.

The criterion of use 'in the course of trade' might, however, be insufficient for exempting from trade mark infringement problematic instances of mixed speech where a non-commercial use of a trade mark is put in a commercial context and takes place in relation to goods and services. The famous 'Lila-Postkarte' case decided by the German Federal Court of Justice well demonstrates such difficulties. ${ }^{21}$ The case concerned postcards of the defendant which included a poetically worded satirical piece in German 'Über allen Wipfeln ist Ruh, irgendwo blökt eine Kuh. Muh!'22 presented on a purple background corresponding with the colour per se mark of the producer of chocolate MILKA and signed by a fictitious poet Rainer Maria Milka (alluding to the German writer Rainer Maria Rilke) thus invoking associations with MILKA and its advertising campaigns. That use was considered by the German Federal Court as falling within the ambit of trade mark law at the stage of applying general infringement criteria despite its artistic aspect. In this case freedom of art did eventually prevail over trade mark ownership, but only at a later stage of assessment where 'due cause' clause with regard to extended protection of trade marks having a reputation was applied (see remarks in point 3.3).

As far as the requirement of 'use in relation to goods or services' is concerned, traditionally this requirement has been understood as covering use made by a third party for the purpose of distinguishing goods and services not originating from the trade mark proprietor. It is worth noting that use not for the purposes of distinguishing goods or services, remains, just as prior to the EU reform, outside of the scope of harmonised EU trade mark law which only optionally allows Member States for providing such a wider protection (Art. 5(5) TMD 2008, Art. 10(6) TMD 2015).

Modern developments have, nevertheless, opened up the question about a wider understanding of an actionable trade mark use under the EU trade mark law. Notably, the Court considered use of a company name in relation to goods or services, even without a direct affixation, as long as the manner of the use allowed establishing a link between the trade name and the goods or services, as falling within the scope of actionable trade mark use. ${ }^{23}$ The reformed legislation clearly mentions use of the sign as a trade or company name or part thereof as an instance of infringing use

\footnotetext{
${ }^{19}$ French Court of Cassation: Greenpeace v Esso, 8.4.2008, case 06-10961; in a similar vein also Greenpeace $v$ Areva, 8.4.2008, case 07-11251.

${ }^{20}$ EWHC: Unilever plc v Griffin [2010] EWHC 899.

${ }^{21}$ German Federal Court of Justice: 3.2.2005, 'Lila-Postkarte', I ZR 159/02, Gewerblicher Rechtsschutz und Urheberrecht, 583 [2005].

22 'It is calm above the tree tops, somewhere a cow is bellowing. Moo!', after Senftleben [21] p. 148, fn. 38 .

${ }^{23}$ Case C-17/06 Céline, EU:C:2007:497, paras. 21-23.
} 
(Art. 10(3)(d) TMD 2015; Art. 9(3)(d) EUTMR 2017). The Court further considered as actionable trade mark use instances of use for the purpose of identifying goods or services of the trade mark owner, among others: use to inform the public about repair and maintenance of original goods, ${ }^{24}$ use to inform about compatibility with original goods, ${ }^{25}$ or use in comparative advertising. ${ }^{26}$ In the latter case use of a sign in comparative advertising in a manner that is contrary to Directive 2006/114/EC (the MCAD) ${ }^{27}$ is now considered an instance of infringing use (Art. 10(3)(f) TMD 2015; Art. 9(3)(f) EUTMR 2017). This development has lead, however, to an erosion of contours of the criterion of use in relation to goods and services, depriving it in practice of its function of a barrier to an over-excessive trade mark protection. ${ }^{28}$ This also has resulted in a reduced relevance of this criterion for the balancing of interests, which justifies searching for proper mechanisms of providing a respective balance elsewhere.

\subsubsection{The function theory}

A further mechanism to be taken under scrutiny is the aforementioned function theory created in the case law of the CJEU with regard to the double identity type of infringement (Art. 10(2)(a) TMD 2015; Art. 9(2)(a) EUTMR 2017). The protection afforded in double identity cases remains, just as prior to the reform, referred to in the respective preambles as absolute (recital 16 of the TMD 2015 and recital 11 of the EUTMR 2017), but the content of this formula has not been clear since the very beginning of the EU trade mark law, especially in the light of various national approaches towards the scope of trade mark rights. ${ }^{29}$

The confined scope of this paper does not allow presenting thoroughly the historic development of the function theory. ${ }^{30}$ Putting it concisely, in the light of the function theory the protection in double identity cases is not absolute in the sense that it would cover any use of an identical mark for identical goods which is not embraced by any of the limitations and exceptions. ${ }^{31}$ The scope of protection according to the function theory is, however, still quite wide and elastic, since infringement can be established when the conduct of a third party compromises in an actual or potential way one of the functions of a trade mark, this not necessarily being only the essential function of guaranteeing the origin of the goods or services to consumers, but also

${ }^{24}$ Case C-63/97 BMW, EU:C:1999:82, para. 42.

${ }^{25}$ Case C-228/03 Gillette, EU:C:2005:177, paras. 33-34.

${ }^{26}$ Case C-533/06 O2 Holdings, EU:C:2008:339, para. 36; Case C-487/07 L'Oréal, EU:C:2009:378, para. 53.

${ }^{27}$ Directive 2006/114/EC of the European Parliament and of the Council of 12 December 2006 concerning misleading and comparative advertising [2006] OJ L 376/21.

${ }^{28}$ Senftleben [21], pp. 146-147.

${ }^{29} \operatorname{Kur}$ [13], p. 436.

${ }^{30}$ See e.g. Kur [13]; Cohen Jehoram [4].

${ }^{31} \mathrm{~A}$ lack of 'absolute' character of protection in this sense in double identity cases was stressed by the Court in Case C-323/09 Interflora EU:C:2011:604, para. 37. 
other (accessory) trade mark functions, ${ }^{32}$ including, but not limited to, the function of guaranteeing the quality of the goods or services in question and communication, investment or advertising function. ${ }^{33}$

The function theory has raised concern among those scholars who perceived it as a potential threat of uncontrolled expansion of exclusive trade mark rights, due to awarding a too-elastic protection of accessory functions embraced by a nonexhaustive catalogue, an unclear relation between protection of accessory functions in double identity cases and in cases of extended protection of trade marks having a reputation and inviting too much unfair competition type of thinking in the process of determining the scope of exclusive trade mark rights. ${ }^{34}$ In line with those concerns the European Commission in its proposal for the EU trade mark law reform of 2013 suggested limiting the scope of protection in double identity cases to the origin function. ${ }^{35}$ This proposal was however met with criticism ${ }^{36}$ and was eventually not adopted in the reformed EU trade mark law, which leaves the shape of the function theory as developed in the case law of the CJEU intact.

The fears connected with the function theory seem, however, to have been to some extent mitigated by the development of the case law in which the Court has employed the general broad formula of the function theory rather as a tool allowing a balancing of interests than a plain tool of expansion of trade mark exclusivity. Symptomatic of this development are keyword advertising cases ${ }^{37}$ in which the Court has taken the perspective of competing interests of trade mark proprietors against interests of advertisers and consuming public in support of its findings concerning the criteria for an interference or a lack thereof with the origin function ${ }^{38}$ or accessory functions. ${ }^{39}$ Further, with regard to the protection of European Union Trade Marks (EUTMs) the function theory has gradually achieved a major significance for justifying exceptions to the EU-wide scope of protection, allowing the denial of an infringement in a part of the EU in which an interference with the functions of a given EUTM or a threat thereof is not present, e.g. for linguistic reasons, and, consequently, excluding this area from the territorial scope of an injunction, ${ }^{40}$ thus preventing an over-excessive effect of the unitary protection of EUTMs.

\footnotetext{
${ }^{32}$ Case C-206/01 Arsenal, paras. 51 and 54; Case C-245/02 Anheuser-Busch, EU:C:2004:717, para. 59; Case C-48/05 Adam Opel, EU:C:2007:55, paras. 21-22; Case C-487/07 L'Oréal, paras. 58-60; Joined Cases C-236/08 to C-238/08 Google, paras. 75-77, Case C-323/09 Interflora, paras. 37-38.

${ }^{33}$ Case C-487/07 L'Oréal, para. 58.

${ }^{34}$ Ohly [16]; Senftleben [21].

${ }^{35}$ Document COM(2013) 0162 final-2013/0089 (COD), Explanatory Memorandum, point 5.1.

${ }^{36}$ JURI Committee documents: PE-522.796 (amendment 73) and PE-516.713 (amendment 23); Sack [18], p. 659; polemically (with regard to exhaustion-related aspects) Senftleben [22], pp. 521-524.

${ }^{37}$ Davis [7], pp. 125-127; Kur, Senftleben [15], p. 15.

${ }^{38}$ Joined Cases C-236/08 to C-238/08 Google, paras. 82-90; Case C-323/09 Interflora, paras. 44-53.

${ }^{39}$ E.g. Joined Cases C-236/08 to C-238/08 Google with regard to the advertising function (paras. 91-98); Case C-323/09 Interflora, with regard to a lack of adverse effect on advertising function (paras. 54-59) and investment function (paras. 60-66).

${ }^{40}$ Case C-235/09 DHL, EU:C:2011:238, paras. 46-48 Case C-223/15 combit, EU:C:2016:719, paras. 2735 and Case C-93/16 Ornua, EU:C:2017:571, paras. 29-32; in the two latter judgments expressly with regard to the likelihood-of-confusion type of infringement regulated in Art. 9(2)(b) EUTMR 2017.
} 
The result is that the function theory does not appear to be a single-edged sword serving only as a tool of uncontrolled expansion of trade mark exclusivity, as it might enable when necessary refusing protection to the trade mark owner. The clear advantage of the function theory rests in its flexibility giving courts a relatively wide margin for a balancing of interests, ${ }^{41}$ which can be already done at the stage of assessing the primary cause of action, prior to moving in a given case to the applicability of express limitations and exceptions.

While one can appreciate a noticeable room for a flexibility of the function theory as a balancing tool with regard to goodwill (accessory) functions, this flexibility might not, however, be robust enough with regard to the origin function. An example of such a situation can be illustrated by the circumstances of the Martin Y Paz case decided by the Court. ${ }^{42}$ The factual background in the main proceedings in Belgium was quite complex. Putting it briefly, two parties, Martin Y Paz and Gauquie ${ }^{43}$ peacefully shared over a long period of time use of several unregistered trade marks with each party using them for slightly different leather goods. As the relations between the parties deteriorated Martin Y Paz registered the said marks in its own name for a wide range of leather goods. An attempt by Gauquie to invalidate those registrations on the ground of bad faith failed due to the lapse of time to file an invalidation action. ${ }^{44}$ It provoked, however, a reaction as Martin Y Paz sued for a trade mark infringement seeking to enjoin Gauquie from using the marks with regard to any leather goods. In response Gauquie filed a counterclaim requesting the court to prohibit on grounds of national unfair competition law use by Martin Y Paz of its own registered marks for other leather goods than those for which Martin Y Paz was using the marks in question during the shared use. The position of the Court on whether considerations flowing out of unfair competition law or doctrines on abuse of rights could affect the exercise of exclusive rights to registered trade marks is discussed elsewhere in this paper (see 3.4). At this point remarks are focused on whether any balancing of interest on the premise of fairness of competition without creating an unjustified market entry barrier for Gauquie could be done at the stage of assessing an interference with the essential function. On one hand the conduct of Martin Y Paz raises concerns, since despite a long-lasting co-operation between both parties Martin Y Paz registered in its name the trade marks in question for a wide range of leather goods and subsequently made an attempt to block the use of those trade marks by Gauquie. On the other hand it would be difficult to deny an infringement of the origin function. As the Advocate General Villalón indicated in his Opinion in Martin Y Paz, a prior shared use could be considered as justifying a lack of interference with the origin function only in exceptional circumstances in which consumers would have become used to the fact that some of the products covered by the trade mark registration originated from the trade mark proprietor and some of those products originated from a third party which

\footnotetext{
${ }^{41}$ As forcefully put forward by AG Kokott in her Opinion in Case C-46/10 Viking Gas, EU:C:2011:222, paras. 45 et seq., notably para. 59; in a similar vein Kur [13], p. 443.

${ }^{42}$ Case C-661/11 Martin Y Paz, EU:C:2013:577.

43 ' Gauquie' is used for Mr David Depuydt and Fabriek van Maroquinerie Gauquie NV acting jointly.

${ }^{44}$ It is not entirely clear, why a cancellation on the ground of bad faith there was precluded, since in the case of bad faith a temporal limitation should not apply—Kur [14], p. 392.
} 
had been sharing the use of the mark with the trade mark owner. Such circumstances could not be established in AG's opinion with regard to the specific case in the main proceedings. ${ }^{45}$ This position demonstrates, however, that the function theory cannot always serve as a tool for providing a balance of interests that would enable achieving an equitable outcome (developed further in 3.4).

Considering the above remarks and putting aside the central problem of whether function theory is a concept which should determine the scope of an exclusive right, it appears justified to assume that the function theory is a positive factor at least to the extent that it can be employed as a mechanism of balancing of interests in double identity cases. However, in the light of the outlined disadvantages it could not be a sufficient sole instrument to achieve the desired purpose. This calls for the need to examine the attention given under the EU trade mark law to other instruments.

\subsection{Limitations and exceptions}

Express limitations and exceptions are a direct and classic tool of providing a proper balance between the interests of trade mark owners and other competing interests. The EU trade mark law has adopted a closed catalogue of limitations and exceptions which was subject to several amendments in the course of the EU trade mark law reform (Art. 14(1) TMD 2015, Art. 14(1) EUTMR 2017) with all limitations and exceptions remaining contingent on the check for compliance with honest practices requirement (Art. 14(2) TMD 2015, Art. 14(2) EUTMR 2017).

As far as the own name and address exception is concerned, in the light of Art. 6(1)(a) TMD 2008 the Court considered it to be applicable not only to names of natural persons, but also to trade names. ${ }^{46}$ This approach was met with criticism. It was argued that such an extension without justification privileged trade names in cases of conflicts with trade marks whereas due to overlapping functions of both types of designations and difficulties on the part of the public in distinguishing between trade names and trade marks, when the former were in fact used in relation to goods and services, the conflicts between them should be resolved on the basis of a temporal priority. It was therefore suggested that the said exception should be limited to natural persons only. ${ }^{47}$

The newly worded exception indeed confines the own name and address exception to natural persons (Art. 14(1)(a) TMD 2015, Art. 14(1)(a) EUTMR 2017) and it has already raised concerns. In the UK case $S k y v S k y K i c k^{48}$ the High Court of England and Wales was considering, if it should request a preliminary ruling from the Court on whether the new exception, already operative with regard to EUTMs, was contrary to several fundamental rights insofar as it limited the scope of the own name defence to natural persons. Specifically, the following fundamental rights and freedoms regulated in the Charter were invoked: freedom to conduct business (Art. 16),

\footnotetext{
${ }^{45}$ Opinion of AG Villalón in Case C-661/11 Martin Y Paz, EU:C:2013:252, paras. 72-75; the AG stressed that such exceptional circumstances were present in Case C-482/09 Budějovický Budvar, EU:C:2011:605; see also Kur [14], pp. 392-393.

${ }^{46}$ Case 245/02 Anheuser-Busch, paras. 77-81; Case C-17/06 Céline, para. 31.

${ }^{47}$ Study [27], pp. 120-121, paras. 2.254-2.255.

${ }^{48}$ [2017] EWHC 1769.
} 
right to property (Art. 17), equality before the law (Art. 20) and non-discrimination (Art. 21). The High Court eventually denied making a reference to the Court prior to the outcome on the merits, but the issue may come up again the future.

As already mentioned, under the new legislation use of the mark as a trade or company name or part thereof is expressly indicated as an example of infringing use (Art. 10(3)(d) TMD 2015; Art. 9(3)(d) EUTMR 2017). The solution to the problem appears to be resting on the circumstance that if use of a trade name is made only for distinguishing a business, such use does not fall within the ambit of EU trade mark law, since the proper balancing of interests is already provided by the excluding effect of the 'use in relation to goods and services' requirement (see 3.1.1). Consequently, with regard to this instance introducing a separate trade name defence appears to be unnecessary. As far as the harmonised trade mark law is concerned, only optionally Member States may prohibit such use pursuant to Art. 10(6) TMD 2015 as use for purposes other than distinguishing goods or services, just as prior to the reform. ${ }^{49}$

As far as use of a trade name made in relation to goods or services is concerned, the argument that it might be very difficult to draw a line between such use of a trade name and use of a trade mark or service mark from the perspective of the relevant public, is sound. The question is, how to approach this issue in the architecture of trade mark law. One possible solution would be the presence of a limitation extending to trade names which viewed through the lens of the general honest practices criterion, would allow taking into account the extent to which the trade name of a third party may be perceived by the relevant public as indicating a link between trade mark owner and the third party's goods or services, as well as the presence of a reputation of the trade mark. ${ }^{50}$ This would mean, however, that a general exemption for trade names in cases of conflict with trade marks would remain a rule, which seems quite difficult to reconcile with the observation that drawing a line between use of a trade name for the purpose of distinguishing goods and services and classic use as a trade mark is regularly very difficult. Such cases in fact concern a collision between two designations that are equal for the relevant public which does not distinguish between the formal legal qualifications of distinctive signs as trade (service) marks or trade names, as long as they are all used in relation to goods and services. For this reason a general exemption for use of trade names would not only endanger the interests of the trade mark owner, but it would also act to the detriment of the public. Therefore a better solution appears to be an avoidance of a general exemption of such use from infringement, ${ }^{51}$ in favour of resolving similar conflicts according to the principle of temporal priority of one of the colliding signs. An exceptional presence of a general exemption which disregards the rule of temporal priority, is justified only with regard to the use of the name and address of natural persons, as it is the right of any individual to be able to commercially exploit their own name and address to

\footnotetext{
${ }^{49}$ Art. 5(5) TMD 2008; Case C-23/01 Robelco, EU:C:2002:706, para. 34; Case C-245/02 Anheuser-Busch, para. 64.

${ }^{50}$ Case C-245/02 Anheuser-Busch, para. 83.

${ }^{51}$ An opposite direction was suggested in the Case C-245/02 Anheuser-Busch, para. 81, which in the light of the current limitation to names of natural persons appears to be no longer valid.
} 
designate their businesses and goods or services, ${ }^{52}$ provided, however, that such use meets the general honest practices requirement.

For the reasons set out above excluding trade names from the scope of the own name and address limitation under the reformed EU trade mark law appears to properly balance the interests of trade mark owners against interests of enterprises using their trade names in relation to goods and services, additionally with a view to securing the interests of the consuming public in avoiding confusion or any other distortion of making market decisions. It should be further stressed that the trade mark owner will normally be unable to request a complete cessation of a use of trade name, since, as indicated above, the actionable trade mark use does not extend to use of a trade name that is not taking place in relation to goods and services for the purpose of distinguishing them. ${ }^{53}$ The advocated view could raise objections that it offers no flexibility with regard to such instances when for reasons of equity a use of a junior trade name made in relation to goods and services should nevertheless be allowed. ${ }^{54}$ If such instances do occur, they should rather encourage the discussion about the permissibility of invoking other balancing tools such as national laws on abuse of rights or unfair competition laws enhanced by the need to protect freedom to conduct business as a fundamental freedom (see 3.4). It might be debatable, however, whether they could justify the potential presence of a general exemption extending to the use of trade names in the EU trade mark law.

As for further limitations and exceptions, an important extension of permitted use under the reformed EU law rests in the addition of a limitation concerning use of nondistinctive signs or indications next to descriptive use limitation (Art. 14(1)(b) TMD 2015, Art. 14(1)(b) EUTMR 2017), the latter already being in place prior to the reform (Art. 6(1)(b) TMD 2008, Art. 12(1)(b) CTMR 2009). It remains to be seen how the amended limitation will operate, in particular what would the relation between the limitation for use of non-distinctive signs and the absolute refusal ground due to a lack of distinctive character (Art. 4(1)(b) TMD 2015, Art. 7(1)(b) EUTMR 2017) be. With regard to the limitation for use of descriptive signs prior to the reform the Court implied early on in Baby Dry that a more lenient approach towards the assessment of descriptiveness or distinctiveness at the stage of registration was justified, because it would still be possible for third parties (potential defendants) to rely on the limitation for descriptive use in infringement proceedings. ${ }^{55}$ In subsequent case law the Court took however a different direction, stressing that the limitation in question had no relevance for the interpretation of the refusal ground for descriptive or nondistinctive signs and did not justify a leniency of the assessment thereof which had to be stringent, in order to prevent trade marks from being improperly registered. ${ }^{56}$ Yet

\footnotetext{
${ }^{52}$ Kur, Senftleben [15], pp. 409-410.

${ }^{53}$ Ibid, p. 411.

${ }^{54}$ Davis, in: Aplin, Davis [1], p. 455, points out the instance of small and medium enterprises honestly adopting their names.

${ }^{55}$ Case C-383/99 P Procter \& Gamble, EU:C:2001:461, paras. 35-37; this argument was put forward even more decisively by AG Jacobs in his Opinion to the cited case, EU:C:2001:203, para. 48.

${ }^{56}$ Joined Cases C-108/97 and C-109/97 Windsurfing Chiemsee, EU:C:1999:230, para. 28; Case C-104/01 Libertel, EU:C:2003:244, paras. 58-59; Case C-64/02 P Erpo Möbelwerk, EU:C:2004:645, para. 45; Case C-51/10 P Agencja Wydawnicza Technopol, EU:C:2011:139, paras. 59-62.
} 
in practice minimal distinctiveness is deemed to be sufficient for a trade mark to be registered ${ }^{57}$ and indeed the approach towards the assessment of distinctiveness at this stage appears to be liberal rather than stringent. ${ }^{58}$ Therefore the very same position of case law enunciating a lack of interrelation between the limitation in question and the absolute refusal grounds could currently operate to the effect that the assessment of non-distinctiveness under the newly worded limitation could allow, when necessary, mitigating the effects of a too-liberal registration practice. It will be crucial in that regard to see how the interests underlying the limitation for use of non-distinctive signs will be defined in case law, and what would their relation to the interests underpinning the refusal grounds due to a lack of distinctiveness or due to descriptiveness be. So far the CJEU has defined the public interest underlying the refusal ground due to a lack of distinctiveness as oriented at the interests of consumers in that the trade marks properly perform against them their essential function of guaranteeing origin of goods and services, rather than at the interests of competitors in having access to commercial exploitation of non-distinctive signs. ${ }^{59}$ By contrast, the 'need to keep free' was considered to be at stake with regard to the assessment of distinctiveness of colours per $s e^{60}$ and with regard to the refusal ground for descriptive signs or indications (Art. 4(1)(c) TMD 2015, Art. 7(1)(c) EUTMR 2017;61 simultaneously, however, 'need to keep free' was considered as not constituting an obstacle for registration in the case of acquired distinctiveness of geographical names and colours per $s e^{62}$ ). This concretisation of public interest with regard to assessment of distinctiveness and descriptiveness at the stage of registration which is tailored to the interests of specific groups, was subject to criticism. ${ }^{63}$ Therefore, even if the said differentiation of underlying public interests was to be upheld in case law with regard to refusal grounds, it can reasonably be argued that at least the limitation for use of nondistinctive (and also descriptive) signs should currently be from the outset interpreted in a wider perspective of all interests involved, including the interests of consumers and also of competitors who should not face an obstacle of an unnecessary market barrier preventing them from using non-distinctive or descriptive signs. ${ }^{64}$ This assertion can be backed by the fundamental freedom to conduct business anchored in Art. 16 of the Charter.

${ }^{57}$ Case T-337/99 Henkel, EU:T:2001:221, para. 44; Case T-139/08 The Smiley Company, EU:T:2009:364, para. 16; Case T-53/13 Vans, EU:T:2014:932, para. 68; Case T-291/16 Anta (China), EU:T:2017:253, para. 17.

${ }^{58}$ Kur in: Kur, Senftleben [15], p. 107.

${ }^{59}$ E.g. Case C-329/02 P SAT.1, EU:C:2004:532, para. 36.

${ }^{60}$ Case C-104/01 Libertel, para. 60.

${ }^{61}$ Joined Cases C-108/97 and C-109/97 Windsurfing Chiemsee, para. 25; Case C-191/01 P Wrigley Jr. Company, EU:C:2003:579, para. 31.

62 Joined Cases C-108/97 and C-109/97 Windsurfing Chiemsee, paras. 47 et seg.; Case C-104/01 Libertel, paras. 67-68.

${ }^{63}$ Study [27], pp. 57-58, paras. 1.47-1.50; Davis [5], pp. 356-365.

${ }^{64}$ In Case C-102/07 adidas, EU:C:2008:217, para. 47 the Court ruled out, however, a possibility of invoking the need-to-keep-free argument as a standalone restriction of the effects of the trade mark with regard to use of descriptive signs and stressed further that relying on this argument involved a prior establishing that an indication used by the defendant related to one of the characteristics of defendant's goods or services. 
A further important change is the introduction of the general open-ended referential use defence which generally exempts use made by a third party for the purpose of identifying or referring to goods or services as those of the proprietor of the trade mark (Art. 14(1)(c) TMD 2015, Art. 14(1)(c) EUTMR 2017). Prior to the reform the referential use exemption covered only the use necessary to indicate the intended purpose of a product or service, in particular as accessories or spare parts (Art. 6(1)(c) TMD 2008; Art. 12(1)(c) CTMR 2009), ${ }^{65}$ which is now mentioned as an example of referential use. Moreover, the general referential use limitation does not include the requirement of necessity of use which, however, has been upheld with regard to the exemplary 'indication of purpose' instance. A longer, open-ended concretisation of instances of referential use limitation was proposed by the European Parliament, ${ }^{66}$ including: necessity of indication of purpose of products or services, comparative advertising compliant with requirements of the MCAD, use in connection with the resale of genuine goods, putting forward a legitimate alternative to the goods or services bearing a trade mark of the proprietor, use for parody, artistic expression, criticism or comment. Eventually the adopted referential use defence only mentions the 'indication of purpose' exemption, ${ }^{67}$ but its formula remains open-ended and is capable of accommodating other instances of referential use too, even if they are not expressly stated. ${ }^{68}$ Moreover, the express qualification in Recitals 27 TMD 2015 and 21 EUTMR 2017 of use made to draw the consumer's attention to the resale of genuine goods and use made for the purpose of artistic expression as being fair as long as it remains in accordance with honest practices in industrial and commercial matters (which is a general criterion for all limitations) implies that at least those two instances have also been noticed by the EU legislator as modalities of referential use, even if they are not expressly mentioned in the provisions of the TMD 2015 and the EUTMR 2017.

The wide referential use exception should be of particular importance in the fragile instances of mixed commercial and non-commercial (artistic, polemical, satirical) use. Even if such instances could, and most likely would, be considered as meeting the widely construed requirement of use 'in the course of trade' (see 3.1.1), they could still be considered under the current wide referential use exception with special attention given to the interest of the public at large in using the mark in public discourse. The interpretation and application of this exception oriented at providing a proper balancing of interests could be backed by the wording of Recital 27 TMD

\footnotetext{
${ }^{65}$ Interpreted by the Court in Case C-228/03 Gillette.

${ }^{66}$ European Parliament legislative resolution of 25.2.2014 on the proposal for a directive of the European Parliament and of the Council to approximate the laws of the Member States relating to trade marks (recast) (COM(2013)0162-C7-0088/2013-2013/0089(COD)) (COM(2013)0162-C70088/2013-2013/0089(COD)), amendment 33.

${ }^{67}$ Use in comparative advertising contrary to the MCAD is, however, indicated as an instance of infringing use (Art. 10(3)(f) TMD 2015; Art. 9(3)(f) EUTMR 2017).

${ }^{68}$ The fact that comparative advertising which is contrary to the MCAD (Art. 10(3)(f) TMD 2015), is positively indicated as an example of infringing use and not as an explicit exemption under the referential use defence, acts to the benefit of the defendant, as it results in placing of the burden of proof of noncompliance with requirements of the MCAD on trade mark owner who needs to evidence the infringing use-Kur, Senftleben [15], pp. 422-423.
} 
2015 and Recital 21 EUTMR 2017 which expressly refer to fundamental rights and freedoms, in particular freedom of expression.

Looking at exceptions and limitations in trade mark law as balancing tools from a more general perspective, it appears that the validity of the traditional rule that limitations and exceptions must be interpreted narrowly could be dubious. ${ }^{69}$ This rule treats exceptions to property rights as privileges for third parties introduced at the expense of the proprietor. Such approach might be appropriate for the property of tangible objects; it fails, however, with regard to intellectual property rights (IPRs). In the case of IPRs the interface between the exclusivity of right-holders and the social and economic need to provide access to IP objects leads to particular tensions, which contradicts treating IPRs as pure economic assets. ${ }^{70}$ With regard to the realm of trade mark law as AG Poires Maduro indicated in his Opinion in the Google cases 'trade mark rights cannot be construed as classic property rights enabling the trade mark proprietor to exclude any other use' ${ }^{71}$ In the UK pre-harmonisation case $G E$ Trade Mark Lord Diplock stated with regard to a right to a registered mark that '[a] right of property of this character calls for an accommodation between the conflicting interests of the owner of the monopoly, of the general public as purchasers of goods to which the trade mark is affixed, and of other traders' ${ }^{72}$ The 'non-classic' nature of the exclusive trade mark right as a property right should justify, in the context of limitations and exceptions, a departure from the perception thereof as privileges for third parties. ${ }^{73}$ Instead they ought to be perceived as regulating tools which are aimed at enabling a proper functioning of trade marks in accordance with their functions and with a view to striking a proper balance between competing interests. This should by no means be read as implying that limitations and exceptions as a rule ought to be interpreted extensively. It is, however, necessary to put emphasis on the balanceoriented role of limitations and exceptions, which calls for a need to avoid any general preference of interests of a specific group of actors at play, in particular trade mark holders.

\section{3 'Due cause' clause}

A separate role in the balancing of interests in EU trade mark law can be performed by the 'due cause' clause which is available, as prior to the reform, in the case of extended protection of trade marks having a reputation (Art. 10(2)(c) TMD 2015, Art. 9(2)(c) EUTMR 2017). ${ }^{74}$ The cited provisions stipulate that protection of a trade mark with a reputation is available where use of a sign without due cause takes unfair

\footnotetext{
${ }^{69}$ Schovsbo [20], pp. 25-26. For a welcoming approach towards a departure from a restrictive interpretation of limitations and exceptions in copyright law in the case law of the CJEU, also on the premise of freedom of expression, see Geiger, Griffiths, Senftleben, Bently, Xalabarder [11].

${ }^{70}$ Davis [6], pp. 1023-1026.

${ }^{71}$ Opinion in Joined Cases C-236/08 to C-238/08 Google, para. 103.

${ }^{72}$ General Electric Co v General Electric Co Ltd; GE TM; Re GE Trade Mark: HL 1972; for a discussion on the interface between 'intellectual commons' and trade mark rights in UK pre-harmonisation case law and the impact of harmonised EU trade mark law on this sphere see Davis [5].

${ }^{73}$ Similarly with regard to the so-called 'Bolar' exemption in patent law Straus [26], pp. 904-905.

${ }^{74}$ Di Cataldo [8].
} 
advantage of, or is detrimental to, the distinctive character or the repute of an earlier trade mark.

The 'due cause' clause has been employed so far in case law, in order to provide a proper balance of interests, also on the premise of freedom of expression and freedom of competition. In the Interflora judgment the 'due cause' clause was invoked in the context of freedom of commercial speech consisting in informing consumers about an alternative offer in an advertisement displayed on the internet on the basis of a keyword corresponding to a trade mark with a reputation, which was considered as falling within the ambit of fair competition and not being without due cause, provided that the advertisement did not concern a mere imitation of the goods or services of the owner of the trade mark with a reputation, it did not cause dilution or tarnishment and it did not adversely affect the functions of the trade mark with a reputation in question. ${ }^{75}$ In this case the interests of competitors in being able to inform about their alternative offers, as well as interests of consumers in obtaining such information, are at stake.

Another example of employing the 'due cause' clause with a view to providing an equitable solution is the Leidseplein judgment in which the Court rejected the traditional approach in Benelux case law (expressed with regard to provisions in Benelux law being the prototype for extended protection of trade marks with a reputation in EU law) construing 'due cause' narrowly as covering only situations in which the defendant was able to invoke objectively overriding reasons for his use of a sign identical with or similar to a trade mark with a reputation. ${ }^{76}$ The Court ruled that the concept of 'due cause' did not only include objectively overriding reasons, but might also relate to the subjective interests of a third party, such as an earlier use of a sign similar to the mark with a reputation. ${ }^{77}$ The Court stressed that the concept of 'due cause' did not intend to resolve a conflict between a registered and unregistered mark or to restrict the rights of the proprietor of the registered mark with a reputation, but to strike a balance between his interests and the interests of the third party using an earlier sign. ${ }^{78}$ It specified further factors to be taken into account for the assessment of 'due cause' in such a case. ${ }^{79}$ This capacity of the 'due cause' clause might be particularly important in those Member States which do not recognise rights in unregistered marks.

The due cause clause has also been employed for the sake of providing a balance of interests on the premise of freedom of artistic expression. In the German 'LilaPostkarte' case an artistic and satirical use of trade marks of the producer of chocolate on postcards was considered, as already mentioned in point 3.1.1, as actionable trade mark use. There was, however, due cause for such use resulting from the need to protect the freedom of art. This case also demonstrates a great advantage of the 'due cause' clause, resting in the fact that reliance on this clause is not precluded in

\footnotetext{
${ }^{75}$ Case C-323/09 Interflora, para. 91; also Opinion of AG Jääskinen in this Case, EU:C:2011:173, para. 99.

${ }^{76}$ Judgment of the Benelux Court of Justice of 1.3.1975 Colgate Palmolive v Bols, International Review of Intellectual Property and Competition Law, 420 [1976].

${ }^{77}$ Case C-65/12 Leidseplein, EU:C:2014:49, paras. 45-48.

${ }^{78}$ Ibid., para. 46.

${ }^{79}$ Ibid., paras. 49-60.
} 
fragile instances of mixed commercial and non-commercial speech in which the infringement claim cannot be denied on the ground that there was no 'use in the course of trade' (see 3.1.1). Ironic commercial allusions to trade marks with a reputation will of course not always constitute 'due cause', as illustrated by the case decided by the Austrian Supreme Court ${ }^{80}$ which concerned the use by the defendant of the mark STYRIAGRA for pumpkin seeds in blue coating, being a humorous combination of the widely recognisable trade mark VIAGRA and the name of the Austrian land STYRIA (from which the pumpkin seeds originated), as well as invoking associations with the appearance of blue Viagra pills. In this case the aspect of taking unfair advantage of a reputation of an earlier mark was considered as prevailing over the argument pertaining to parody use.

In the light of the case law cited above 'due cause' appears to be a useful tool for providing a necessary flexibility in trade mark law which is not limited to any closed catalogue of instances. This general capacity of 'due cause' seems to find support in the Leidseplein judgment, since the rejection by the Court of the restrictive Benelux interpretation should resonate much wider than just the specific issue of balancing of interests of proprietors of trade marks having a reputation against subjective interests of competitors linked with an earlier use of mark in circumstances such as those in the main proceedings in Leidseplein. The Court appears to have treated 'due cause' as an open-ended general clause aimed at the balancing of various interests. ${ }^{81}$ If so construed, 'due cause' can serve as an internal instrument of trade mark law which constitutes an elastic gateway for interests competing with the exclusivity of the trade mark proprietor to be taken into account, allowing inter alia a considerable room for arguments derived from fundamental rights and freedoms, which, again, under the reformed EU law can be supported by the wording of Recital 27 TMD 2015 and Recital 21 EUTMR 2017. ${ }^{82}$

Under the reformed EU law invoking 'due cause' remains limited to extended protection of trade marks with a reputation only. ${ }^{83}$ Introduction of such a general fair use clause for all types of infringement with an exemplary catalogue of instances of fair use was, however, suggested. ${ }^{84}$ Given that the EU trade mark law reform was recently completed a possible change to that effect is at the moment hardly in sight. While the amended catalogue of express limitations and exceptions, in particular the wide referential use limitation, might have to some extent remedied the lacking infrastructure aimed at providing a necessary flexibility in trade mark law, the issue of introducing an open-ended due cause (fair use) defence should still be considered as a point of doctrinal debate. A usual argument raised on the occasion of considering an introduction of fair use defences in IP regimes in the EU is the lack of experience of civil law judges with such clauses, which might be a detrimental factor for maintaining a legal certainty. The validity of this argument might be challenged as open-ended general

${ }^{80}$ Austrian Supreme Court: judgment of 22.9.2009, 17 0b 15/19v, ECLI:AT:0GH0002:2009:0170OB 00015.09V.0922.000.

${ }^{81}$ Case C-65/12 Leidseplein, paras. 27-49 preceded by the heading 'Scope of the concept of "due cause"'.

${ }^{82}$ In a similar vein Schovsbo [20], p. 23.

${ }^{83}$ Confirmed in Case C-65/12 Leidseplein, para. 35 .

${ }^{84}$ Study [27], p. 123 para. 2.266; Senftleben et al. [23]. 
clauses have already existed for a long time in continental civil law systems ${ }^{85}$ and judges are not unaccustomed to the application thereof. ${ }^{86}$ Moreover, with regard to trade mark law specifically, the application of the due cause clause has so far shown that courts can effectively employ it to provide a fair and equitable balance of interests in the case of extended protection and there is no reason to assume that the same would not happen, if the due cause clause was applicable to all types of trade mark infringement.

\subsection{National correction mechanisms}

Until now the analysis focused on legal instruments of securing a proper balance of interests which were inherent in trade mark law. A further question is, however, whether national laws located outside of the realm of trade mark law might 'externally' affect the exercise of exclusive trade mark rights with a view to providing a respective balance of interests.

Such a possibility was put into doubt by the Court in the judgment in Case Martin $Y \mathrm{Paz}$ at least with regard to the application of national unfair competition law or private law doctrines on abuse of rights. The quite complex factual background has been already outlined above (see 3.1.2). The case concerned a shared prior use of several trade marks by two parties which subsequently were registered by just one of them (Martin Y Paz) in its own name. The registrations could not be invalidated on the ground of bad faith due to the lapse of time and they were later invoked as a basis for a trade mark infringement claim against the defendant (Gauquie). The issue at stake was whether the defendant could, first, successfully raise a plea that the infringement action constituted an abuse of rights, because the trade mark owner had with no justification withdrawn its consent for the peaceful shared use of marks and, second, whether the defendant could even achieve a further reaching effect by successfully requesting the court by means of a counterclaim on the grounds of unfair competition law to enjoin the trade mark owner from using its own registered marks for those goods which during the peaceful shared use were the subject of the defendant's activity. ${ }^{87}$

In its key statement addressing this issue the Court ruled that 'save for the specific cases governed by Article 8 et seq. of that directive [Dir. 89/104, subsequently TMD 2008], a national court may not, in a dispute relating to the exercise of the exclusive right conferred by a trade mark, limit that exclusive right in a manner which exceeds the limitations arising from Articles 5 to 7 of the directive'. ${ }^{88}$ Consequently, in the view of the Court the respective legal instruments oriented at providing a balance of interest must be found within the provisions of trade mark law without employing national unfair competition laws or provisions on abuse of rights. ${ }^{89}$ While the Court

\footnotetext{
${ }^{85}$ Such as the German good faith clause (Treu und Glauben; e.g. in $\S 157$ or $\S 242$ of the German Civil Code) or the Polish clause of principles of social co-existence (e.g. in Art. 5 or Art. $353^{1}$ of the Polish Civil Code).

${ }^{86}$ Senftleben [25], pp. 249 et seq.

${ }^{87}$ Case C-661/11 Martin Y Paz, paras. 35 and 50.

${ }^{88}$ Ibid., para. 55.

${ }^{89}$ Ibid., para. 60.
} 
ruled that the trade mark owner who had unlawfully withdrawn the consent for a shared use might be ordered to pay a compensation, it made it simultaneously clear that it was not possible to prolong for an unspecified period the shared use of trade marks where both parties no longer had the joint intention of sharing it. ${ }^{90}$

The Court appears to be treating trade mark law in Martin Y Paz as a self-sufficient and autonomous system which is able to solve tensions between the scope of trade mark rights and considerations of fairness of competition within its own sphere. This position could rest on the assumption that trade mark law, being an essential element of undistorted competition, is already designed to provide a competition-friendly balance on its own. A good example of such a perception of trade mark law could be found in the Court's Ford decision ${ }^{91}$ which concerned the interface between trade mark law and design law. The Court rejected a wide interpretation of the repair clause in Art. 110 of the Community Design Regulation No 6/2002 ${ }^{92}$ which would allow the producer of replacement parts to fully reproduce them by including also the trade mark of the original producer. The Court indicated that the need for a wide understanding of the repair clause could not be substantiated by the need to preserve undistorted competition. In the key statement the Court found that '[a]s regards the view [... ] that the European Union's objective of protecting the system of undistorted competition requires the application of Article 14 of Directive 98/71 and Article 110 of Regulation No 6/2002 to be extended to protection as trade marks, it should be noted that that objective was already taken into account [emphasis by the author] by the EU legislature in Directive 2008/95 and Regulation No 207/2009'. ${ }^{93}$ Consequently the Court reiterated in Ford the Martin Y Paz formula and ruled that any limitation to trade mark rights, including that connected with putting original mark on the replacement part, must be found within the realm of trade mark law. ${ }^{94}$

The position of the Court in Martin Y Paz is debatable. While one can appreciate that trade mark law is indeed to a large extent designed to provide a balance of interest on the premise of undistorted competition with its own tools, the circumstances of Martin Y Paz case demonstrate that it is not necessarily such a self-sufficient system, as the Court desires it to be. On one hand the conduct of the claimant can raise objections as to its compliance with fairness of competition, since despite a long-lasting prior shared use the claimant registered the trade marks in question in its own name for a wide range of leather goods and subsequently made an attempt to enjoin the defendant from using the trade marks in relation to goods which had been the subject of the defendant's activity under the peaceful shared use. On the other hand, providing an equitable balance of interests by trade mark law instruments may be impossible, as, first, for reasons set out above, it would be hard to deny an interference with the origin function of the registered marks (see 3.1.2), and, second, express limitations and exceptions would not be relevant in circumstances such as those of Martin Y Paz,

\footnotetext{
${ }^{90}$ Ibid., para. 61.

${ }^{91}$ Case C-500/14 Ford, EU:C:2015:680.

${ }^{92}$ Council Regulation (EC) No 6/2002 of 12.12 .2001 on Community Designs.

${ }^{93}$ Case C-500/14 Ford, para 43.

${ }^{94}$ Ibid., para 44.
} 
which the Court duly observed. ${ }^{95}$ In those Member States which recognise rights in unregistered marks, a conflict such as in Martin Y Paz would most likely be resolved in accordance with the temporal priority of conflicting signs. ${ }^{96}$ The position in Martin Y Paz might, however, have drastic effects for those regimes of trade mark protection, such as the Benelux law, which do not recognise rights in unregistered signs and protect them only by unfair competition law or general civil law. If one takes a position that a prevalence of registered marks in such an instance would be a formalistic solution which would run against principles of equity, it becomes evident that treating trade mark law as a closed system entirely capable of resolving conflicts between competing interests with its own instruments is not justified. ${ }^{97}$

After the EU trade mark law reform the permissibility of limiting the exercise of exclusive trade mark rights by means of external corrective instruments provided in national laws could be supported by the need to take account of fundamental rights and freedoms in the process of applying trade mark law legislation, as reflected in the preamble of the TMD 2015 and the EUTMR 2017. National correction instruments, such as doctrines on abuse of rights or unfair competition laws can be treated as mechanisms securing at the level of ordinary legislation the guarantee of fundamental rights and freedoms, in particular freedom of expression and-in circumstances such as those of Martin Y Paz-freedom to conduct business. Therefore application of such mechanisms should not be per se precluded in exceptional situations in which consideration of fairness and equity call for it and which cannot be remedied by the application of internal instruments of trade mark law.

\section{Conclusions}

The increasing quest for giving a consideration to competing interests in trade mark law which manifested itself in case law, did not pass unnoticed in the EU trade mark law reform, as the TMD 2015 and the EUTMR 2017 have to a certain degree improved the legal framework suitable for providing a respective balance, in particular on the premise of freedom of expression and freedom of competition, with regard to trade mark infringement. As a result the centre of gravity of providing the proper balance might be located at different stages of assessing an infringement action, as compared to the situation prior to the reform, depending naturally on the type of infringement and the circumstances of the case. Under the new legislation the balancing role could be attributed in particular to the open-ended referential use limitation which can accommodate instances of e.g. artistic, polemical or satirical use, as well as purely commercial referential use, while probably reducing the role for that purpose of general notions of trade mark law, such as 'use in the course of trade' or 'use in relation to goods and services' which have already become widely construed. The employment of the 'due cause' clause for a similar purpose should also remain on the increase. On the other hand, quite contrary, the role of the general infringement

\footnotetext{
${ }^{95}$ Case C-661/11 Martin y Paz, paras. 56-57.

${ }^{96}$ So with regard to German law Kur [14], p. 394.

${ }^{97}$ Ibid., p. 395.
} 
criterion of 'use in relation to goods and services' will likely increase with regard to providing a proper balance between use of trade names and use of trade marks since the own name and address limitation under its new wording which is confined to natural persons, could not come to aid with regard to use of trade names.

Another important element in the reformed EU trade mark law is the reference to fundamental rights and freedoms in the preambles of TMD 2015 and EUTMR 2017 , which is a clear signal of the need to take them into account in the process of interpreting and applying trade mark laws not just in exceptional circumstances, but potentially in all instances whenever the need for a proper balance calls for it. ${ }^{98}$ The reference to fundamental rights and freedoms supports the view that in balancing of interests with regard to the scope of trade mark rights any tendencies towards a general preference of a specific group of actors at play must be avoided. In particular, as far as the catalogue of limitations and exceptions is concerned, this necessitates a departure from the traditional understanding that limitations and exceptions must be interpreted narrowly in the interest of trade mark owners. If they are to function properly as tools for providing a proper flexibility, they must be construed with the view to taking account of all competing interests involved.

Finally, precluding a permissibility of application of external correction mechanism contained in national legal orders, as enunciated by the Court in Martin Y Paz, is challengeable. Arguably, arguments derived from references to fundamental rights and freedoms in the recitals of the new TMD and EUTMR give an incentive to rethink the issue of whether the reformed EU trade mark law is indeed immune to such mechanisms.

Open Access This article is distributed under the terms of the Creative Commons Attribution 4.0 International License (http://creativecommons.org/licenses/by/4.0/), which permits unrestricted use, distribution, and reproduction in any medium, provided you give appropriate credit to the original author(s) and the source, provide a link to the Creative Commons license, and indicate if changes were made.

\section{References}

1. Aplin, T., Davis, J.: Intellectual Property Law. Text, Cases and Materials, 3rd edn. Oxford University Press, Oxford (2017)

2. Bently, L.: From communication to thing: historical aspects of the conceptualisation of trade marks as property. In: Dinwoodie, G.B., Janis, M.D. (eds.) Trademark Law and Theory: A Handbook of Contemporary Research. Edward Elgar, Cheltenham (2008)

3. Burrell, R., Gangjee, D.: Trade marks and freedom of expression-a call for caution. Int. Rev. Intellect. Prop. Compet. Law, 544-569 (2010)

4. Cohen Jehoram, T.: The function theory in European trade mark law and the holistic approach of the CJEU. Trademark Report. 102, 1243-1253 (2012)

5. Davis, J.: European trade mark law and the enclosure of the commons. Intellect. Prop. Q., 342-367 (2002)

6. Davis, J.: A European constitution for IPRs? Competition, trade marks and culturally significant signs. Common Mark. Law Rev., 1005-1026 (2004)

7. Davis, J.: Promoting the public interest and the European Trade Mark Directive: a contradictory approach. ERA Forum 14, 117-129 (2013)

8. Di Cataldo, V.: The trade mark with a reputation in EU Law - some remarks on the negative condition: “without due cause”. Int. Rev. Intellect. Prop. Compet. Law, 833-845 (2011)

${ }^{98}$ Schovsbo [20], p. 7. 
9. Fhima, I.S.: Trade marks and free speech. Int. Rev. Intellect. Prop. Compet. Law, 293-321 (2013)

10. Geiger, C.: Trade marks and freedom of expression - the proportionality of criticism. Int. Rev. Intellect. Prop. Compet. Law, 317-327 (2007)

11. Geiger, C., Griffiths, J., Senftleben, M., Bently, L., Xalabarder, R.: Limitations and exceptions as key elements of the legal framework for copyright in the European Union—opinion of the European Copyright Society on the Judgment of the CJEU in Case C-201/13 Deckmyn. Int. Rev. Intellect. Prop. Compet. Law, 93-101 (2015)

12. von Kapff, P.: Fundamental rights in the practice of the European Trade Mark and Designs Office (OHIM). In: Geiger, C. (ed.) Research Handbook on Human Rights and Intellectual Property. Edward Elgar, Cheltenham (2015)

13. Kur, A.: Trade marks function, don't they? CJEU jurisprudence and unfair competition principles. Int. Rev. Intellect. Prop. Compet. Law, 434-454 (2014)

14. Kur, A.: Vorrangtheorie à la Luxemburg? Zu den Auswirkungen der Funktionsrechtssprechung und der Entscheidung Martin Y Paz/Gauquie. In: Alexander, C., et al. (eds.) Festschrift für Helmut Köhler zum 70. Geburtstag, München (2014)

15. Kur, A., Senftleben, M.: European Trade Mark Law. A Commentary, Oxford University Press, Oxford (2017)

16. Ohly, A.: Keyword advertising or why the ECJ's functional approach to trade mark infringement does not function. Int. Rev. Intellect. Prop. Compet. Law, 879-881 (2010)

17. Ramsey, L.P., Schovsbo, J.: Mechanisms for limiting trade mark rights to further competition and free speech. Int. Rev. Intellect. Prop. Compet. Law, 671-700 (2013)

18. Sack, R.: Kritische Anmerkungen zur Regelung der Markenverletzungen in den Kommissionsvorschlägen für eine Reform des europäischen Markenrechts. Gewerbl. Rechtssch. Urheberr., 657-666 (2013)

19. Sakulin, W.: Trademark Protection and Freedom of Expression. An Inquiry into the Conflict between Trademark Rights and Freedom of Expression under European Law, Wolters Kluwer Law \& Business, Alphen aan den Rijn (2011)

20. Schovsbo, J.: 'Mark My Words'-Trademarks and Fundamental Rights in the EU (August 7, 2017). Available at SSRN: https://ssrn.com/abstract=2928031 [accessed 8 January 2018]

21. Senftleben, M.: Adapting EU trademark law to new technologies-back to basics? In: Geiger, C. (ed.) Constructing European Intellectual Property: Achievements and New Perspectives. Edward Elgar, Cheltenham (2013)

22. Senftleben, M.: Function theory and international exhaustion: why it is wise to confine the double identity rule in EU trade mark law to cases affecting the origin function. Eur. Intellect. Prop. Rev. 518-524 (2014)

23. Senftleben, M., et al.: Recommendation on measures to safeguard freedom of expression and undistorted competition in EU trade mark law. Eur. Intellect. Prop. Rev. 337-343 (2015)

24. Senftleben, M.: Free signs and free use-how to offer room for freedom of expression within the trademark system. In: Geiger, C. (ed.) Research Handbook on Human Rights and Intellectual Property. Edward Elgar, Cheltenham (2015)

25. Senftleben, M.: The perfect match—civil law judges and open-ended fair use provisions. Am. Univ. Int. Law Rev. 33(1), 231-286 (2017)

26. Straus, J.: The Bolar exemption and the supply of patented active pharmaceutical ingredients to generic drug producers: an attempt to interpret Article 10(6) of Directive 2004/27. J. Intellect. Prop. Law Pract., 895-908 (2014)

27. Study on the Overall Functioning of the European Trade Mark System, Max Planck Institute for Intellectual Property and Competition Law, Research Paper No. 12-13, Munich, Max Planck Institute 2011, available at: http://ec.europa.eu/internal_market/indprop/docs/tm/20110308_allensbachstudy_en.pdf (accessed 8 January 2018) 